\title{
JOURNAL.RU
}

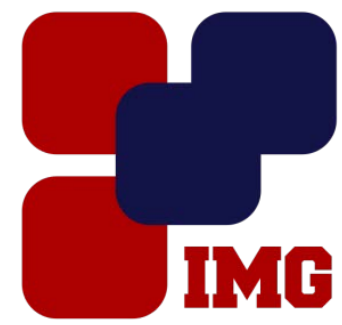

IVanov
Management
GROUP

Борисов А.В., Зинчук С.В., Дущанова К.С.,Журбин И.В. Институт физико-химических и биологических проблем почвоведения РАН

Пущино, Россия

doi: 10.18411/lj-25-12-2016-2-02

idsp 000001:lj-25-12-2016-2-02

\section{Почвенно-геохимические подходы к выявлению границ культурного слоя на археологических памятниках, разрушенных распашкой}

\section{Аннотация}

Проведено исследование химических и геохимических свойств почв средневекового аграрного памятника Кушманское селище-3 в Ярском районе Удмуртской Республики. На территории памятника и прилегающей территории проводился отбор образцов и лабораторные анализы почв из пахотного горизонта. Установлено, что на месте поселения сохраняются повышенные значения содержания фосфатов и магнитной восприимчивости по сравнению с фоновыми почвами. Это позволяет устанавливать наличие археологического памятника на основе почвенных свойств.

Ключевые слова: Средневековье, поселение, фосфаты, органический углерод, магнитная восприимчивость

Активная сельскохозяйственная деятельность второй половины XX в. вызвала разрушение значительного количества археологических памятников. В средней полосе России и в Предуралье распашке подвергались практически все открытые участки. В первую очередь сглаживались рельефные признаки поселений: сохранившиеся оборонительные валы; участки заплывших рвов; локальные неровности поверхности, связанные с фундаментами наземных построек, котлованами заглублённых сооружений, печами, горнами и т.п. При этом археологический материал включался в пахотный слой и вызывал изменения его химических и геохимических свойств. Изучению изменений свойств пахотного слоя на территории археологического памятника и возможности установления границ памятника по почвенным свойствам посвящена данная работа.

Одним из ключевых памятников Средневековья на территории Удмуртской республики является Кушманское городище Учкакар IX-XIII вв. н.э. На его территории фиксируется мощный культурный слой, известно три 
линии оборонительных сооружений [2, с. 43-47]. В непосредственной близости от Учкакаранаходится Кушманское селище-3. В настоящее время территория селища полностью распахана и следов памятника на поверхности не обнаружено. Согласно данным геофизического исследования культурный слой сохранился только в северо-восточной части селища. В геоморфологическом плане эта зона соответствует нижней части пологого склона северной экспозиции, где эрозионные процессы наименее интенсивны и создаются предпосылки для консервации культурного слоя. На этом участке был заложен археологический шурф, подтвердивший наличие поселения IX-XIII вв. н.э.

В рамках данного исследования проведены почвенные исследования Кушманского III селища - типичного средневекового поселения региона. На территории памятника проводился отбор образцов почв из пахотного горизонта по трансекте длиной 90 м в пикетах, расположенных через 6 м. Собственно поселение располагалось в пределах пикетов 8-16 (Рис. 1). Пикеты 1-7 расположены за пределами памятника с напольной строны. В качестве контроля был выбран пикет 18, приуроченный к участку с сильной эрозией, где культурный слой не сохранился.

В кернах в полевых условиях определялись морфологические свойства почвенно-грунтового материала (однородность, цвет, наличие включений) и гранулометрический состав. Кроме того, в усредненных образцах, отобранных из пахотного горизонта, было проведено определение содержание органического углерода и фосфатов. Синхронное повышение содержания фосфатов (значения более 50 мг/100 г) и органического углерода (значения более $3 \%$ ) позволяет предположить наличие культурного слоя даже в условиях высокой интенсивности эрозии почв. Содержание фосфора определяли при экстрагировании $2 \mathrm{n} \mathrm{HCl}$. Получаемые при такой обработке данные, в целом, довольно близки к валовому содержанию фосфора [4, с. 311]. Определение тенденций в изменении содержания фосфатов на территории памятника позволяет установить зоны максимального антропогенного влияния на почву определить границы сохранившегося культурного слоя.

Содержание органического углерода определялось по методу Тюрина [1, c. 130-136]. Увеличение содержания органического углерода также можно рассматривать как результат антропогенной деятельности. Это связано с поступлением в почвах поселений больших объемов органического материала: растительных остатков, золы, угля, бытового мусора.

Магнитная восприимчивость образцов определялась портативным каппаметром КТ-5 (Чехия). В археологических реконструкциях величина магнитной восприимчивости является показателем пирогенного влияния на почву. Эти данные позволяют установить наличие мест разведения огня (очаги, печи), а также скопления пирогенно-преобразованного почвенно-грунтового материала (места выбросов или складирования продуктов очистки очагов, производственные ямы и др.) [3. С. 117-128]. Результаты определений представлены на рисунке 1. 
Как видно из рисунка, наиболее достоверный след археологического памятника в современном почвенном покрове удается реконструировать при помощи анализа содержания фосфатов в пахотном слое. Так, в данном случае границы превышения содержания фосфатов практически полностью соответствуют границам памятника.Довольно точно присутствие культурного слоя удается реконструировать при помощи определения магнитной восприимчивости. Что касается содержания органического углерода, то в данном случае на распределение этого показателя оказывают влияние иные факторы, в частности, наличие западины и эрозионное накопление мелкозема.

Таким образом, с помощью определения содержания фосфатов в пахотном слое можно с высокой степенью надежности определять исходное наличие поселения и реконструировать его границы.
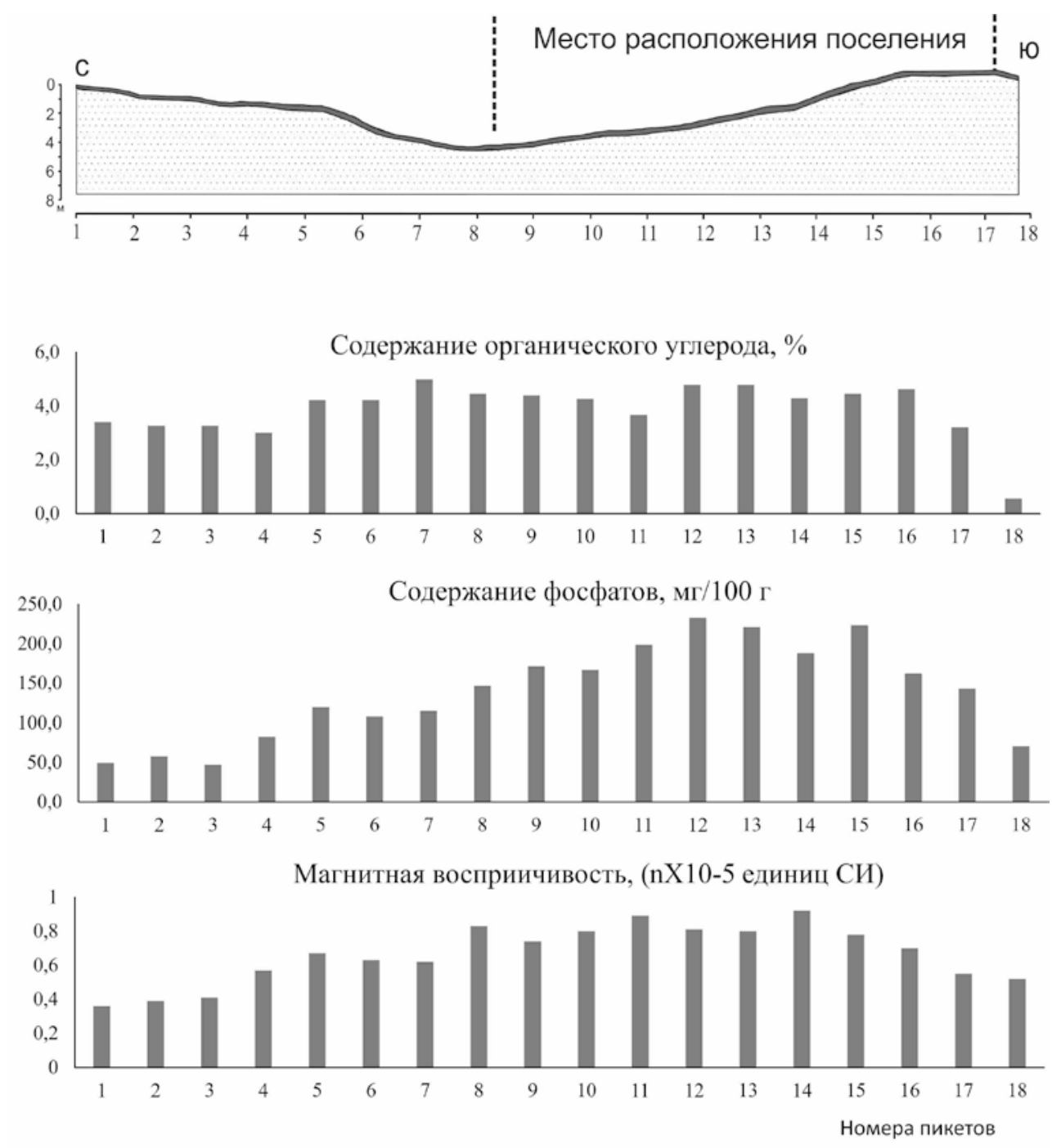

Рис. 1. Химические свойства почв на территории памятника

Работа выполнена при поддержке РФФИ, грант № 15-06-04239 а 


\section{Литература}

1. Аринушкина Е.В. Руководство по химическому анализу почв. М.: Изд-во МГУ, 1970. $488 \mathrm{c}$.

2. Иванова М.Г., Журбин И.В. Археологические и геофизические исследования средневековых поселений в долине реки Чепца // Российская археология, 2014, № 1. С. 40-53.

3. Fassbinder J., Stanjek H. 1993. Occurrence of Biogenic Magnetite in Soils from Archaeological Sites. ArchaeologiaPolona 31: 117-128.

4. Holliday V.T., Gartner W.G. 2007 Methods of Soil P Analysis in Archeology. JournalofArchaeologicalScience 34: 301-333. 